\title{
PENGARUH MODEL PEMBELAJARAN KOOPERATIF TIPE JIGSAW DENGAN BANTUAN MEDIA GAMBAR TERHADAP MOTIVASI DAN HASIL BELAJAR IPA SISWA KELAS V SD 110 JEKKA
}

\author{
Fatmawati $^{1}$ \\ ${ }^{1}$ SDN 47 Joalampe Sinjai, Sinjai, Sulawesi Selatan, Indonesia. \\ fatmawati19720514@mail.com
}

\begin{abstract}
Abstrak
Penelitian ini bertujuan untuk Menganalisis pengaruh model pembelajaran kooperatif tipe jigsaw dengan bantuan media gambar terhadap motivasi belajar dan hasil belajar IPA pada siswa kelas $V$ SD 110 Jekka. Pada konsep mengidentifikasi organ gerak hewan dan manusia. Metode penelitian yang digunakan adalah metode quasi eksperimen yang dilakukan selama 5 kali pertemuan ditambah pretest dan post test. Sampel dalam penelitian ini terdiri dari dua kelompok, yaitu kelompok eksperimen yang berjumlah 20 siswa dan kelompok kontrol yang juga berjumlah 20 siswa. Berdasarkan analisis data pengujian hipotesis dengan uji $t$ ada pengaruh yang signifikan pembelajaran kooperatif tipe jigsaw dengan bantuan media gambar terhadap hasil belajar IPA siswa kelas V SD 110 Jekka tahun pembelajaran 2019. Hal ini ditunjukkan oleh nilai thitung $=2,346743$ dan 2,380 $>$ ttabel $=1,989$ dengan taraf signifikan 5\%, sehingga $\mathrm{HO}$ ditolak yang berarti ada pengaruh model pembelajaran sehingga hipotesis diterima. Oleh karena itu dapat disimpulkan bahwa terdapat pengaruh penggunaan model pembelajaran kooperatif tipe jigsaw terhadap hasil belajar IPA. Hal ini sesuai dengan kelebihan model pembelajaran tipe jigsaw, yaitu dapat merangsang motivasi belajar dan dapat membantu timbulnya asosiasi dengan peristiwa lain yang mudah diingat.
\end{abstract}

Kata Kunci: Pengaruh Model Pembelajaran Kooperatif tipe Jigsaw, Motivasi, Hasil belajar

\begin{abstract}
This study aims to analyze the effect of the jigsaw cooperative learning model with the help of picture media on learning motivation and science learning outcomes in class V students of SD 110 Jekka. On the concept of identifying animal and human motion organs. The research method used was a quasiexperimental method conducted during 5 meetings plus pretest and post test. The sample in this study consisted of two groups, namely an experimental group of 20 students and a control group of 20 students. Based on the analysis of hypothesis testing data with the $t$ test, there is a significant influence on the type of jigsaw cooperative learning with the help of picture media on the learning outcomes of students in class V of SD 110 Jekka in the 2019 learning year. This is indicated by the tcount $=2.346743$ and 2.380 > ttable $=1.989$ with a significant level of 5\%, so $\mathrm{HO}$ is rejected which means there is an influence of the learning model so that the hypothesis is accepted. Therefore it can be concluded that there is an influence of the use of the Jigsaw cooperative learning model on the learning outcomes of Natural Sciences. This is in accordance with the advantages of the jigsaw type learning model, which can stimulate learning motivation and can help the emergence of associations with other memorable events.
\end{abstract}

Keyword: The Effect of Jigsaw Cooperative Learning Model, Motivation, Learning Outcomes 


\section{Pendahuluan}

Pendidikan merupakan suatu proses mencerdaskan kehidupan bangsa, meningkatkan kualitas manusia Indonesia, serta mewujudkan tujuan nasional bangsa Indonesia, proses pendidikan yang dilakukan di sekolah merupakan kegiatan pendidikan belajar dan mengajar untuk mencapai tujuan pendidikan adalah salah satu tanggung jawab dan beban semua pihak yang bergerak dalam dunia pendidikan.

UU RI No. 20 Tahun 2003 tentang Sistem Pendidikan Nasional pada pasal 1 menyatakan: "Pendidikan adalah usaha sadar dan terencana untuk mewujudkan suasana belajar dan proses pembelajaran agar peserta didik secara aktif mengembangkan potensi dirinya untuk memiliki kekuatan sprituil keagamaan, pengendalian diri, kepribadian, kecerdasan, akhlak mulia serta keterampilan yang diperlukan dirinya, masyarakat, Bangsa dan Negara".

Pentingnya suatu pendidikan bagi manusia dijelaskan pada sabda Rusulullah saw disebuah haditsnya yang berbunyi

$$
\text { من أر اد الدنيا فعليه بالعلم ومن أر اد الآخرة فعليه بالعلم ومن أر اد هما فعليه بالعلم }
$$

Artinya: Barang siapa menginginkan dunia harus dengan ilmu, barang siapa menginginkan akhirat harus dengan ilmu, dan barang siapa kedua-duanya harus dengan ilmu." (HR. Bukhari dan Muslim)

Allah swt juga menyajikan kedudukan yang tinggi bagi orang- orang yang berilmu, sebagaimana firman-Nya dalam surat Al-Mujaadilah ayat 11.

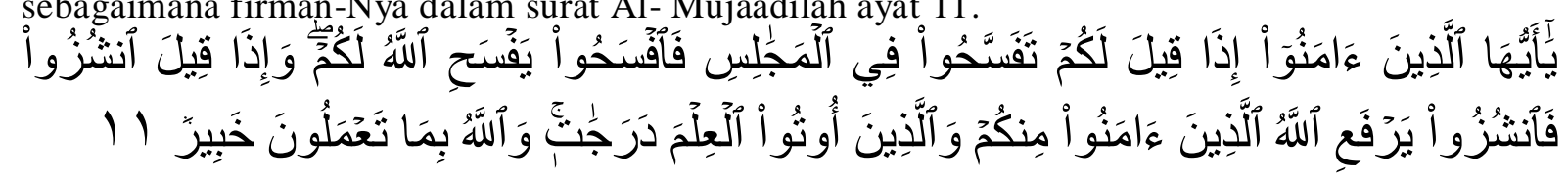

Artinya: Hai orang-orang beriman apabila kamu dikatakan kepadamu: "Berlapanglapanglah dalam majlis", maka lapangkanlah niscaya Allah akan mem beri kelapangan untukmu. Dan apabila dikatakan: "Berdirilah kamu", maka berdirilah, niscaya Allah akan meninggikan orang-orang yang beriman di antaramu dan orang- orang yang diberi ilmu pengetahuan beberapa derajat dan Allah Maha Mengetahui apa yang kamu kerjakan.

Pembelajaran adalah upaya membelajarkan siswa untuk belajar. Suyitno mendefiniskan pembelajaran merupakan usaha untuk membentuk kondisi yang mendukung kemampuan, minat, bakat, serta kebutuhan siswa agar tercipta interaksi yang optimal (Fitriani, 2019: 104)

Kegiatan pembelajaran akan melibatkan siswa mempelajari sesuatu dengan cara efektif dan efisien (Riyanto, 2009:131). Pemilihan model ini sangat dipengaruhi oleh sifat dari materi yang akan diajarkan, juga dipengaruhi oleh tujuan yang akan dicapai dalam pengajaran tersebut dan tingkat kemampuan peserta didik. Salah satu pembelajaran di sekolah adalah pembelajaran Ilmu Pengetahuan Alam (IPA). Pembelajaran IPA mulai diajarkan dari tingkat Sekolah Dasar sampai Perguruan Tinggi. Berdasarkan penelitian pendahuluan yang telah dilaksanakan bahwa siswa SD 110 Jekka mempunyai permasalahan dengan memperoleh hasil belajar IPA sesuai dengan standar yang telah ditetapkan.

Hasil belajar siswa kelas $\mathrm{V}$ tergolong masih sangat rendah karena terdapat beberapa siswa yang nilainya belum mencapai kriteria ketuntasan minimal (KKM) yang telah ditentukan yaitu 65. Selain itu mayoritas siswa terlihat kurang aktif dan kurang antusias pada saat proses pembelajaran berlangsung, serta pemahaman siswa terhadap materi masih sangat rendah. Hal ini disebabkan pada saat proses pembelajaran guru masih menjelaskan secara lisan materi ajar di depan kelas dengan hanya mengacu pada buku paket saja, dan guru kurang memaksimalkan dalam penggunaan 
media yang sudah tersedia untuk menunjang proses belajar mengajar. Berikut presentase nilai ulangan semester ganjil siswa kelas V SD 110 Jekka.

Tabel 1 Persentase Nilai Ulangan Semester Ganjil Siswa Kelas V SD 110 Jekka Tahun Ajaran 2018/2019

\begin{tabular}{|c|c|c|c|c|}
\hline \multirow[t]{2}{*}{ No } & \multirow[t]{2}{*}{ Kelas } & \multicolumn{2}{|c|}{ Nilai } & \multirow{2}{*}{$\begin{array}{c}\text { Jumlah Siswa } \\
\text { (Orang) }\end{array}$} \\
\hline & & 00-64 & $\geq 65$ & \\
\hline \multirow[t]{2}{*}{1} & $\mathrm{VA}$ & 17 & 3 & 2 \\
\hline & $\%$ & 85 & 15 & 100 \\
\hline 2 & $\mathrm{VB}$ & 16 & 4 & 2 \\
\hline
\end{tabular}

(Sumber: Wali Kelas VA dan V B SD 110 Jekka)

Data di atas menunjukkan bahwa siswa kelas V A yang berjumlah 20 orang dengan nilai siswa yang mencapai KKM sebanyak 3 orang dengan persentase sebesar $15 \%$. Sedangkan siswa yang mendapat nilai di bawah KKM pada kelas V A yang berjumlah 17 orang siswa dengan persentase sebesar $85 \%$. Sedangkan kelas V B yang berjumlah 20 orang siswa dengan nilai siswa yang mencapai KKM sebanyak 4 orang siswa dengan persentase sebesar $18 \%$ dan siswa yang mendapat nilai di bawah KKM pada kelas V B yang berjumlah 17 orang siswa dengan persentase sebesar $82 \%$. Kondisi ini menyebabkan siswa yang memperoleh nilai di bawah KKM harus mengikuti remidial.

Menurut Savage dalam Rusman (2011:203), Cooperative Learning adalah suatu pendekatan yang menekankan kerjasama dalam kelompok, sehingga model pembelajaran kooperatif tipe Jigsaw ini diharapkan mampu mengatasi masalah rendahnya hasil belajar siswa kelas V SD 110 Jekka. Model pembelajaran ini menekankan keaktifan, partisipasi, dan kerjasama siswa dalam proses pembelajaran. Hal ini sangat relevan dengan karakteristik siswa kelas $\mathrm{V}$ yang berada pada periode operasional konkret, dimana salah satu ciri yang dimiliki siswa tersebut adalah selalu ingin beradaptasi, berpikir kualitas, dan sudah biasa melihat suatu permasalahan dari sudut pandang yang berbeda (Budiman, 2006:44)

\section{Metode}

\subsection{Jenis penelitian}

Metode penelitian yang digunakan dalam penelitian ini adalah metode eksperimen, yaitu quasi eksperimen. Ciri-ciri dari quasi eksperimen adalah mempunyai kelompok kontrol tetapi tidak dapat berfungsi sepenuhnya untuk mengontrol variable-variabel luar yang mempengaruhi pelaksanaan eksperimen. Pada penelitian ini peneliti menggunakan desain penelitian pretestposttest.

Penelitian ini memiliki dua kelompok kelas yang dipilih secara random, kemudian diberi pretest untuk mengetahui keadaan awal adakah perbedaan antara kelompok eksperimen dan kelompok kontrol. Pada kelas eksperimen menggunakan Model Pembelajaran Kooperatif Tipe Jigsaw dengan Bantuan Media Gambar, sedangkan pada kelas kontrol menggunakan model konvensional berupa metode ceramah dan tanya jawab.

Penelitin eksperimen ini terdiri atas tiga tahapan, yaitu pra-penelitian, perencanaan dan tahap pelaksanaan penelitian, dengan rincian sebagai berikut:

a. Pendahuluan: 1) Peneliti membuat surat izin penelitian pendahuluan ke sekolah;2) Melakukan penelitian pendahuluan untuk mengetahui kondisi sekolah, jumlah kelas dan siswa yang akan dijadikan subjek penelitian, serta cara mengajar guru IPA; 3) Menentukan kelas eksperimen 
Volume 4, No. 2, 2019

ISSN (print) : 2527-578X

ISSN (Print) : 2715-6818

Homepage : http://journal.iaimsinjai.ac.id/index.php/JPDK

b. Tahap Perencanaan: 1) Membuat rencana pelaksanaan pembelajaran (RPP) untuk kelas eksperimen dengan menggunakan model pembelajaran kooperatif tipe jigsaw; 2) Menyiapkan instrumen penelitian.

c. Tahap Pelaksanaan: 1) Mengadakan pretest pada kelas eksperimen; 2) Melaksanakan penelitian pada kelas eksperimen dengan motode pembelajaran kooperatif tipe jigsaw; 3) Mengadakan post-test pada kelas eksperimen; 4) Mengumpulkan, mengolah, dan menganalisis data hasil pretest dan posttest; 5) Membuat laporan hasil penelitian.

\subsection{Teknik Analisis Data}

\subsubsection{Motivasi Belajar}

a. Uji Keterbacaan Item untuk mengukur sejauh mana keterbacaan instrument.

b. Uji Validitas Butir Item terhadap seluruh item yang terdapat dalam angket yang mengungkap motivasi belajar siswa. Kegiatan uji validitas butir item bertujuan untuk mengetahui apakah instrument yang digunakan mampu mengukur apa yang diinginkan. Uji validitas dilakukan dengan menggunakan rumus korelasi product moment dengan angka kasar, dengan bantuan program SPSS 16.00 for windows dengan rumus:

$$
r_{\text {hitung }}=\frac{n\left(\sum x y\right)-\left(\sum x\right)\left(\sum y\right)}{\sqrt{\left\{n \cdot \sum x^{2}-\left(\sum x\right)^{2}\right\}\left\{n \cdot \sum y^{2}-\left(\sum y\right)^{2}\right\}}}
$$

Berdasarkan perhitungan statistic dengan bantuan software Microsoft Excel 2007 dan SPSS didapatkan item-item yang memadai dan yang harus dieliminasi yang tersaji pada tabel 2 berikut.

Tabel 2 Hasil Uji Validasi

\begin{tabular}{|c|c|c|}
\hline Kesimpulan & Item & Jumlah \\
\hline Valid & $\begin{array}{c}2,4,5,6,7,9,10,11,12,13,14,15,16,18,19,20,21,22,23,24,25,2 \\
6,27,28,29,30,31,32,33,34,36,37,38,39\end{array}$ & 42 \\
\hline Tidak Valid & $1,3,8,17,35,40$ & 8 \\
\hline
\end{tabular}

Tabel 4 Kisi-kisi Instrumen motivasi belajar

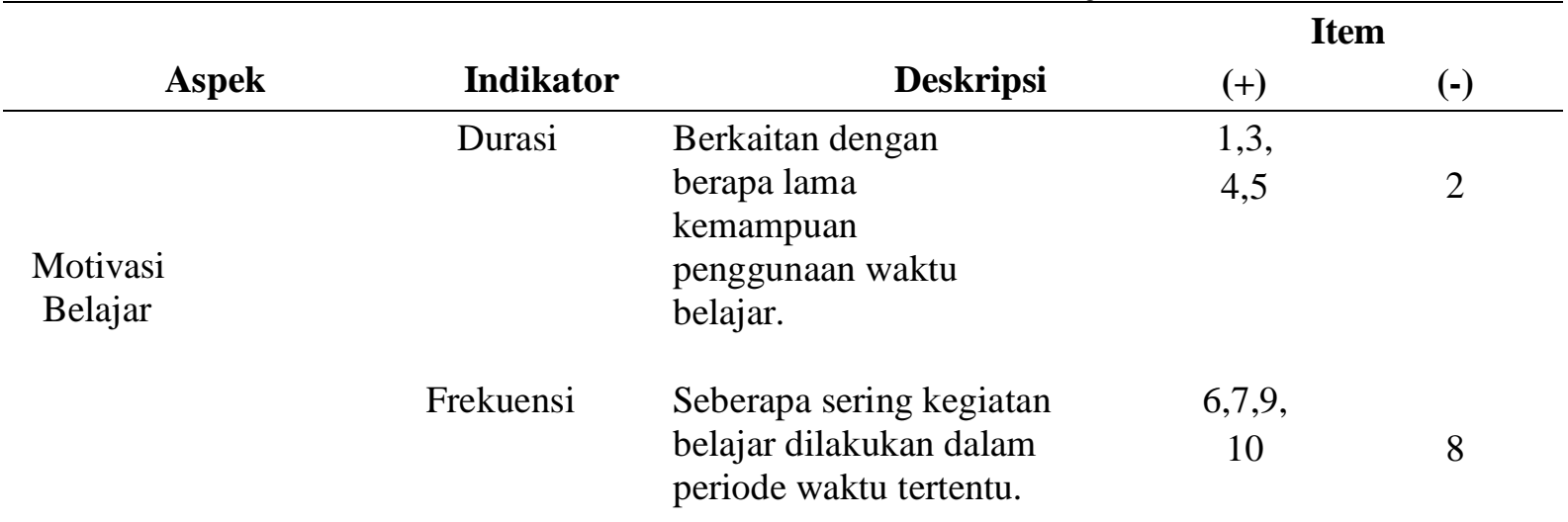




\begin{tabular}{|c|c|c|c|c|}
\hline \multirow[t]{4}{*}{\begin{tabular}{|l} 
JURNAL \\
\\
\\
\end{tabular}} & \multicolumn{4}{|c|}{$\begin{array}{l}\text { JURNAL } \\
\text { Pendidikan Dasar dan Keguruan } \\
\text { Volume 4, No. 2, 2019 } \\
\text { ISSN (print) : 2527-578X } \\
\text { ISSN (Print) }: \text { 2715-6818 } \\
\text { Homepage } \quad \text { http://journal.iaimsinjai.ac.id/index.php/JPDK }\end{array}$} \\
\hline & Persistensi & $\begin{array}{l}\text { Seberapa tetap dan lekat } \\
\text { terhadap tujuan kegiatan } \\
\text { belajar. }\end{array}$ & $\begin{array}{c}11,12 \\
14\end{array}$ & 13,15 \\
\hline & $\begin{array}{c}\text { Ketabahan } \\
\text { dan keuletan }\end{array}$ & $\begin{array}{l}\text { Ketabahan, keuletan dan } \\
\text { kemampuan dalam } \\
\text { menghadapi kesulitan untuk } \\
\text { mencapai tujuan kegiatan } \\
\text { belajar. }\end{array}$ & 16,19 & $\begin{array}{l}17,18, \\
20,21\end{array}$ \\
\hline & Devosi & $\begin{array}{l}\text { Pengabdian dan } \\
\text { pengorbanan (uang, tenaga, } \\
\text { pikiran, bahkan jiwa) untuk } \\
\text { mencapai tujuan kegiatan } \\
\text { belajar }\end{array}$ & $\begin{array}{c}22,23,25 \\
27,28\end{array}$ & 24,26 \\
\hline
\end{tabular}

\begin{tabular}{|c|c|c|c|}
\hline $\begin{array}{l}\text { Tingkatan } \\
\text { Aspirasi }\end{array}$ & $\begin{array}{l}\text { Maksud, cita-cita, rencana, } \\
\text { sasaran atau target yang } \\
\text { hendak dicapai dengan } \\
\text { kegiatan belajar yang } \\
\text { dilakukan. }\end{array}$ & $\begin{array}{c}29,30,31 \\
32,33\end{array}$ & \\
\hline $\begin{array}{l}\text { Tingkatan } \\
\text { Kualifikasi }\end{array}$ & $\begin{array}{l}\text { Prestasi yang dicapai dari } \\
\text { kegiatan belajar. }\end{array}$ & & 34,35 \\
\hline Arah Sikap & $\begin{array}{l}\text { Positif atau negatif } \\
\text { sikap terhadap kegiatan belajar }\end{array}$ & $\begin{array}{l}36,38 \\
\quad 40\end{array}$ & 37,39 \\
\hline
\end{tabular}

\subsubsection{Uji Reliabilitas Instrumen}

Pengujian reliabilitas dilakukan untuk mengetahui suatu instrument dapat dipercaya untuk digunakan sebagai alat pengumpulaan data (Arikunto, 2010:221). Suatu tes dapat dikatakan mempunyai taraf kepercayaan tinggi jika tes tersebut dapat memberikan hasil yang tetap. Uji reliabilitas instrument motivasi belajar dilakukan dengan memanfaatkan SPSS for windows versi 16 metode alpha. Reliabilitas angket motivasi belajar dapat dilihat pada tabel 5 berikut:

Tabel 5 Hasil Uji Reliabilitas Instrumen Motivasi Belajar

\begin{tabular}{cc}
\hline \multicolumn{2}{c}{ Reliability Statistics } \\
\hline Cronbach'sं Alpha & N of Items \\
0,935 & 42 \\
\hline
\end{tabular}

Kriteria tolok ukur koefisien reliabilitas yaitu:

$$
\begin{array}{ll}
0,00-0,19 & : \text { derajat keterandalan sangat rendah } \\
0,20-0,39 & : \text { derajat keterandalan rendah } \\
0,40-059 & : \text { derajat keterandalan cukup } \\
0,60-079 & : \text { derajat keterandalan tinggi } \\
0,80-1,00 & : \text { derajat keterandalan sangat tinggi }
\end{array}
$$


Hasil uji reliabilitas dengan memanfaatkan program SPSS for windows versi 16 metode alpha didapat nilai reliabilitas instrument motivasi belajar sebesar 0,935. Merujuk pada klasifikasi rentang koefisien reliabilitas, maka reliabilitas instrument motivasi belajar berada pada kategori sangat tinggi, yang menunjukkan bahwa instrument yang digunakan sangat baik dan dapat dipercaya sebagai alat pengumpul data

\subsection{Hasil Belajar}

\section{Nilai Gain Ternomalisasi}

tes ini dilakukan untuk melihat pengaruh Model Pembelajaran Kooperatif Tipe Jigsaw dengan Bantuan Media Gambar terhadap motivasi dan hasil belajar siswa. Hal ini dapat dilakukan dengan menggunakan rumus uji gain menurut Meltzer sebagai berikut:

$$
\mathrm{g}=\frac{\text { skor postes }- \text { skor pretes }}{\text { skor edeal }- \text { skor pretes }}
$$

Tabel 6 Klasifikasi Nilai Gain

\begin{tabular}{cc}
\hline Nilai Gain Ternormamlisasi & Interpretasi \\
\hline $0,7<\mathrm{g}<$ & Tinggi \\
$0,3 \stackrel{\circ}{\circ} \mathrm{g} \leq \circ 0,7$ & sedang \\
$0<\mathrm{g}<$ & Renda \\
\hline
\end{tabular}

b. Uji Prasyarat

1) Uji normalitas, untuk mengetahui apakah sampel yang diteliti berdistribusi nomal atau tidak dengan menggunakana uji lillefors. Adapun tahapan untuk uji normalitas adalah sebagai berikut:

a) Menetapkan hipotesis

$\mathrm{H}_{0}$ : sampel berasal dari populasi berdistribusi normal

$\mathrm{H}_{1}$ : sampel tidak berasal dari populasi berdistribusi normal

b) Mangurutkan data sampel dari kecil ke besar

c) Menentukan nilai Zi dari tiap-tiap data, dengan rumus

$Z=\frac{X i-X}{s}$

d) Menentukan besar peluang untuk masing-masing nilai $\mathrm{Z}_{\mathrm{i}}$ berdasarkan tabel $\mathrm{Z}_{\mathrm{i}}$ sebut dengan $\mathrm{f}\left(\mathrm{Z}_{\mathrm{i}}\right)$.

e) Menghitung frekuensi komulatif dari masing-masing nilai $\mathrm{Zi}$ sebut dengan $\mathrm{S}\left(\mathrm{Z}_{\mathrm{i}}\right)$.

f) Menentukan nilai $L_{0}$ dengan rumus $F\left(Z_{i}\right)-S\left(Z_{i}\right)$ kemudian menentukan nilai mutlaknya.

g) Mengambil nilai yang paling besar dan bandingkan dengan $L_{t}$ dari table Liliefors.

h) Adapun kriteria pengujian adalah sebagai berikut: Tolak $\mathrm{H}_{0}$ jika $\mathrm{Lh}_{\mathrm{h}}>\mathrm{Lt}$ terima $\mathrm{H} 0$ jika $\mathrm{Lh} \leq \mathrm{Lt}$

2) Uji Homogenitas, untuk ini untuk mengetahui kesamaan antara dua keadaan atau populasi. Apakah sampel yang diteliti berdistribusi homogen atau tidak dengan menggunakan dua varians atau uji fisher.

$$
\mathrm{F}=\frac{S_{1}^{2}}{S_{2}^{2}}
$$


Volume 4, No. 2, 2019

ISSN (print) : 2527-578X

ISSN (Print) : 2715-6818

Homepage : http://journal.iaimsinjai.ac.id/index.php/JPDK

Keterangan:

F : Homogenitas

$\mathrm{S}_{1}^{2} \quad$ : Varians terbesar

$\mathrm{S}_{2}{ }^{2} \quad$ : Varians terkecil

Adapun kriteria untuk uji homogenitas $(0,05)$ ini adalah: Ho diterima jika Fh $\leq \stackrel{\circ}{\circ} \mathrm{Ft}$

Ho ditolak jika $\mathrm{Fh}>\mathrm{Ft}$

3) Uji Hipotesis

Hipotesis Uji: Ho: $\mu_{1} \geq \mu_{2}$

$\mathrm{H} 1: \mu_{1}>\mu_{2}$

Untuk menguji hipotesis di atas, penulis dalam penelitian ini menggunakan rumus statistik yaitu uji kesamaan dua rata-rata berikut:

$$
t_{\text {hitung }}=\frac{\bar{x}_{1}-\bar{x}_{2}}{\sqrt{\frac{\left(n_{1}-1\right) s_{1}{ }^{2}+\left(n_{2}-1\right) s_{2}{ }^{2}}{n_{1}+n_{2}-2}\left(\frac{1}{n_{1}}+\frac{1}{n_{2}}\right)}}
$$

Keterangan:

X1: Rata-rata kemampuan kemampuan metakognisi sampel eksperimen

$\mathrm{X}_{2}$ : $\quad$ Rata - rata kemampuan kemampuan metakognisi sampel kontrol

n1: $\quad$ Banyak sampel eksperimen n2 : Banyak sampel kontrol

S1: $\quad$ Standar Deviasi dari sampel eksperimen

S2: $\quad$ Standar Deviasi dari sampel control

S: $\quad$ Standar Deviasi

Kriteria pengujian adalah:

1) Ho diterima jika thitung $\geq$ tabel

2) Ho ditolak jika thitung $\leq$ tabel

\section{Hasil dan Pembahasan}

Adapun hasil penelitian dapat dilihat pada tabel 7 berikut.

Tabel. 7 Hasil Penelitian Pengaruh Model Pembelajaran Kooperatif

Tipe Jigsaw Menggunakan Bantuan Media Gambar terhadap Hasil

$$
\text { Belajar IPA Siswa }
$$

\begin{tabular}{ccccc}
\hline $\begin{array}{c}\text { Rumusan } \\
\text { Masalah }\end{array}$ & $\begin{array}{c}\text { Hasil } \\
\text { Penelitian }\end{array}$ & $\begin{array}{c}\text { Kriteria } \\
\text { Interprestasi }\end{array}$ & Interprestasi & \multirow{2}{*}{ Kesimpulan } \\
\hline
\end{tabular}




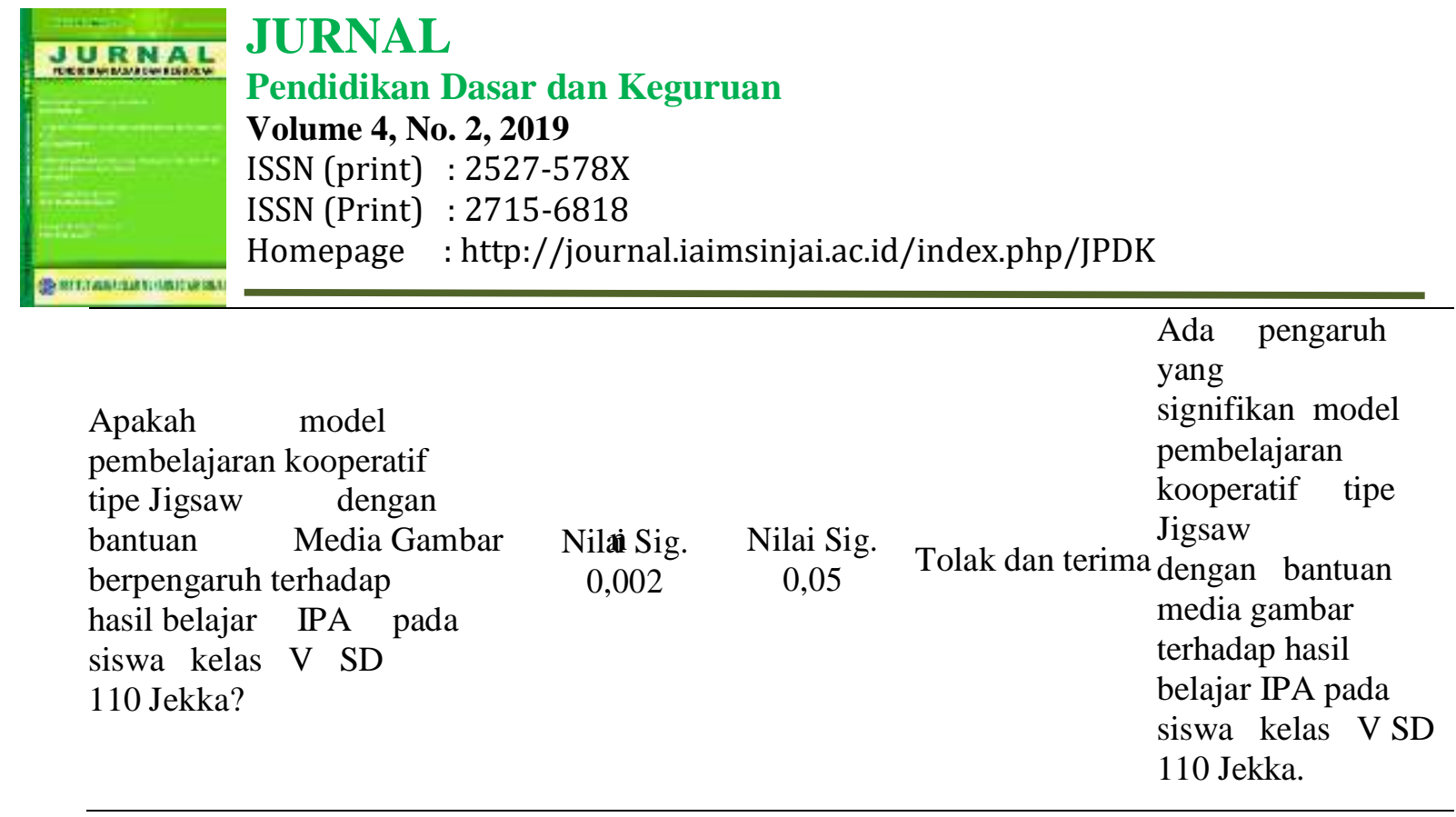

Hasil pengujian MANOVA untuk data nilai hasil belajar dengan nilai Sig. $0,002<0,05$, artinya nilai Sig. untuk hasil belajar siswa semuanya signifikan, maka Ho ditolak dan $\mathrm{H} 1$ diterima. Ini artinya terdapat perbedaan hasil belajar siswa pada pembelajaran IPA antara kelas yang menggunakan model pembelajaran kooperatif tipe jigsaw menggunakan media gambar dengan kelas yang menggunakan model pembelajaran konvensional.

Hasil penelitian tersebut menunjukkan bahwa model pembelajaran kooperatif tipe jigsaw menggunakan media gambar lebih baik dibandingkan dengan model pembelajaran konvensional. Dengan adanya model pembelajaran kooperatif tipe jigsaw menggunakan media gambar seperti ini siswa menjadi lebih aktif dan lebih menghargai dalam bertukar pendapat dengan teman satu kelompoknya. Hal ini sesuai dengan teori yang mengatakan bahwa model pembelajaran jigsaw adalah salah satu tipe pembelajaran kooperatif yang mendasarkan pada suatu ide bahwa siswa bekerja sama dalam belajar kelompok dan sekaligus masing-masing bertanggung jawab pada aktivitas belajar anggota kelompoknya, sehingga seluruh anggota kelompok dapat menguasai materi pelajaran dengan baik. Untuk itu, pembelajaran kooperatif sangat tepat pada pembelajaran IP A karena siswa dapat berpikir secara analitis, kritis, dan kreatif.

Dengan adanya model pembelajaran kooperatif tipe jigsaw menggunakan media gambar siswa lebih bisa memahami materi yang sedang dipelajari. Selain itu, dari hasil observasi yang dilakukan siswa yang berada di kelas eksperimen (V B) lebih konsentrasi dan bersemangat tinggi untuk mengikuti kegiatan pembelajaran dan juga saat mengerjakan soal-soal yang diberikan daripada siswa yang di kelas kontrol (V A). Hal ini ditunjukkan dengan seriusnya siswa dalam menyelesaikan masalah baik individu maupun kelompok dan juga rata- rata nilai yang diperoleh oleh kelas eksperimen lebih baik daripada rata- rata yang diperoleh kelas kontrol.

Hasil penelitian tersebut juga sesuai dengan penelitian Edy Suroso bahwa ada pengaruh yang signifikan pembelajaran kooperatif tipe jigsaw berbantuan media gambar terhadap hasil belajar IPA siswa kelas V SD 110 Jekka tahun pembelajaran 2019. Hal ini ditunjukkan oleh nilai $t_{\text {hitung }}=$ 2,346743 dan 2,380 $>\mathrm{t}_{\text {tabel }}=1,989$ dengan taraf signifikan 5\%, sehingga $\mathrm{H}_{0}$ ditolak yang berarti ada pengaruh model pembelajaran kooperatif tipe jigsaw berbantuan media gambar terhadap hasil belajar belajar IPA siswa kelas V SD 110 Jekka tahun pelajaran 2019.

\section{Simpulan}

Berdasarkan hasil penelitian dan pembahasan di atas dapat diketahui bahwa ada pengaruh penggunaan model pembelajaran kooperatif tipe Jigsaw dengan bantuan Media Gambar berpengaruh terhadap motivasi belajar dan hasil belajar IPA pada siswa kelas V SD 110 Jekka. Hal ini dapat dibuktikan dengan hasil uji t yang dilakukan berdasarkan perbandingan nilai pre-test dan post-test antara kelas eksperimen dan kelas kontrol. Oleh karena itu, penggunaan model pembelajaran kooperatif learning dengan tipe jigsaw sangat dianjurkan dalam pelaksanaan pembelajaran IPA untuk 
siswa Sekolah Dasar. Selain dapat mengasah daya analisis kritis siswa, model pembelajaran ini juga dapat memberikan kesempatan kepada siswa untuk berinteraksi dan belajar menghargai pendapat tean sebaya.

\section{Daftar Pustaka}

Ahmadi, Khoiru dan Sofan Amri. (2011). Mengembangkan Pembelajaran IPA Terpadu. Jakarta: Prestasi Pustaka.

Arikunto, Suharsimi. (2008). Prosedur Penelitian Suatu Pendekatan Praktek. Jakarta: Rineka Cipta

Arnie, Fajar. (2004). Portofolio dalam Pembelajaran IPA. Bandung: Remaja Rosdakarya

Bambang, Warsita. (2008). Teknologi Pembelajaran Landasan \& Aplikasinya. Jakarta: Rineka Cipta.

Budiman, Nandang. (2006). Memahami Perkembangan Anak Usia Sekolah Dasar. Jakarta : Depdiknas Dirjen Dikti Direktorat Ketenagaan.

Dimyati, dan Mujiono. (2009). Belajar Pembelajaran, Jakarta: Rineka Cipta.

Depdiknas. (2006). Bunga Rampai Keberhasilan Guru dalam pembelajaran. Jakarta: Depdiknas.

Djemari, Mardapi. (2008). Teknik Penyusunan Instrumen dan Nontes. Yogyakarta: Mitra Cendikia Offset.

Fitriani. Nurjannah. (2019). Peranan E-Learning Dalam Pembelajaran Matematika di Sekolah Menengah Pertama (SMP). Journal on Pedagogical Mathematics Volume 1, No. 2, April 2019, pp. 102-110.

Volume 1, No. 2, April 2019, pp. 102-110

Huda, Miftahul. (2011). Cooperative Learning. Yogyakarta: Pustaka Pelajar.

Hamalik, Oemar. (2001). Proses Belajar Mengajar. Jakarta: PT. Bumi Aksara.

Hamdani. (2010). Strategi Belajar Mengajar. Bandung: Pustaka Setia.

Hidayati. (2004). Pendidikan Ilmu Pengetahuan Sosial di Sekolah Dasar. Yogyakarta: IKIP Yogyakarta.

I Ketut Tastra, dkk. (2013). Pengaruh Penggunaan Model Pembelajaran Kooperatif Tipe Jigsaw Terhadap Hasil Belajar Ditinjau dari Motivasi Berprestasi Siswa Kelas VII SMP Negeri 4. e-Journal Program Pascasarjana Universitas Pendidikan Ganesha Jurusan Pendidikan Dasar Vol III Sumber : http://pasca.undiksha.ac.id/e-journal. Diunduh pada 10 Januari 2017.

Isjoni. (2009). Cooperatif Learning. Bandung : Alfabet

Komalasari, Kokom. (2011). Pembelajaran Kontekstual. Bandung: PT. Refika Aditama Lie Anita. (2007). Cooperative Learning. Jakarta : Grasindo.

Luh Sri Sudharmini, dkk. (2014). Pengaruh Model Pembelajaran Kooperatif Tipe Jigsaw Terhadap Motivasi Belajar Dan Hasil Belajar IPA Siswa Kelas V Sekolah Dasar Gugus IV Jimbaran, Kuta Selatan. e-Journal Program Pascasarjana Universitas Pendidikan Ganesha Program Studi Pendidikan Dasar Vol IV (Cetakan ke-1:9) Sumber : http://pasca.undiksha.ac.id/e-journal. Diunduh pada 10 Januari 2017.

Mulyani, Sumantri. Johar Permana. ( 2001). Strategi Belajar Mengajar. Bandung: CV Maulana Musfiqon. (2012). Metodologi Penelitian Pendidikan. Jakarta: PT. Prestasi Pustakaraya. Narbuko, Cholid. (2001). Metodologi Penelitian. Bandung: Bumi Aksara

Purwanto. (2009). Evaluasi Hasil Belajar. Surakarta : Pustaka Belajar

-------, M.Ngaliman, MP. (2004). Psikologi Pendidikan. Bandung: Remaja Rosda Karya.

Riduwan. (2012). Belajar Mudah Penelitian (Untuk Guru-Karyawan dan Peneliti Pemula). Bandung: Alfabeta.

Riesa Dewi Setianingrum. (2016). Pengaruh Penerapan Tipe jigsaw Terhadap Hasil Belajar IPA Siswa Kelas IV SD N 2 Sabranglor. Jurnal Pendidikan Guru Sekolah Dasar Program Studi Pendidikan Guru Sekolah Dasar, Jurusan Pendidikan Sekolah Dasar, Fakultas Ilmu 
Homepage : http://journal.iaimsinjai.ac.id/index.php/JPDK

Pendidikan, Universitas Negeri Yogyakarta. Vol VI (Cetakan-1:7) Sumber : http://journal.student.uny.ac.id. Diunduh pada 11 Januari 2017.

Rusman. (2010). Model-model Pembelajaran. Bandung : Mulia Mandiri Press

-. (2012). Model-Model Pembelajaran Mengembangkan Profesionalisme Guru. Jakarta: PT. Raja Grafindo Persada

Sagala, Syaiful. (2008). Konsep dan Makna Pembelajaran. Jakarta. Alfabeta Bandung.

Sangadji, Etta Mamang, dkk. (2010). Metodologi Penelitian (Pendekatan Praktis dalam Penelitian). Yogyakarta: Andi.

Sudijono, Anas. (2009). Pengantar Evaluasi Pendidikan, Jakarta: PT. Raja Grafindo Persada

Sugiyono. (2012). Metode Penelitian Pendidikan. Bandung: Alfabeta.

Susilo, Joko. (2006). Gaya Belajar Menjadikan Makin Pintar, Yogjakarta: PINUS. Sutirman. 2013. Media Dan Model-Model Pembelajaran Inovatif. Yogyakarta: Graha Ilmu.

Shoimin Aris. (2014). 68 model pembelajaran inovatif dalam kurikulum 2013.Yogyakarta:Ar-Ruzz Media.

Slameto. (2010). Belajar dan Faktor-faktor yang Mempengaruhinya. Jakarta: Rineka Cipta.

Soehartono, Irawan. (2004). Metode Penelitian Sosial. Bandung: Remaja Rosdakarya Offset. (cetakan keenam).

Solihatin, Etin. (2009). Cooperatif Learning Analisis Model Pembelajaran IPA. Jakarta: Bumi Aksara.

SU Ischak. (2000). Pendidikan IPA di SD. Jakarta: Universitas Terbuka.

Sudjarwo, Basrowi. (2009). Manajemen Penelitian Sosial. Bandung : CV. Mandar Maju.

Suryani, Agung. (2012). Strategi belajar Mengajar. Yogyakarta: Penerbit Ombak.

Triyono. (2013). Metode Penelitian Pendidikan. Yogyakarta: Penerbit Ombak.

Trihendradi, C. (2005) Step by Step SPSS 13 Analisis Data Statistik. Yogyakarta: Andi

Uno Hamzah. (2008). Model Pembelajaran Menciptakan Proses Belajar Mengajar Yang Kreatif Dan Efektif. Jakarta: PT Bumi Aksara.

Yamin Martinis. (2013). Strategi dan metode dalam model pembelajaran. Jakarta: Referensi (GP Press Group). 